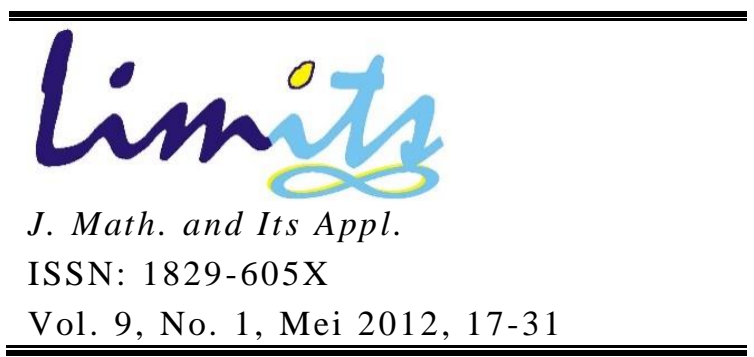

\title{
REGISTRASI CITRA PADA DOMAIN FREKUENSI MENGGUNAKAN METODE POWER CEPSTRUM
}

\author{
Kartika Mahanani $^{1}$, Suhud Wahyudi², Budi Setiyono ${ }^{3}$, Imam \\ Mukhlash ${ }^{4}$ \\ 1,2,3,4 Institut Teknologi Sepuluh Nopember \\ ${ }^{4}$ imam@matematika.its.ac.id
}

\begin{abstract}
Abstrak
Penyampaian informasi dapat dilakukan melalui gambar. Gambar atau bisa disebut citra dapat kehilangan informasi yang terkandung didalamnya jika citra tersebut berkualitas buruk, seperti buram, berbintik, ataupun gelap. Sehingga diperlukan suatu teknik yang dapat mengubah kualitas citra menjadi lebih baik dari sebelumnya dan salah satu teknik yang dapat digunakan adalah teknik Super Resolusi.

Teknik Super Resolusi merupakan teknik yang digunakan untuk membangun citra beresolusi lebih tinggi dari kumpulan citra yang beresolusi lebih rendah. Dalam teknik ini terdapat dua langkah utama yaitu registrasi dan rekonstruksi. Registrasi merupakan kegiatan yang dilakukan untuk memperoleh nilai pergeseran diantara dua citra yang memiliki pergeseran diantaranya. Registrasi Citra dilakukan pada domain frekuensi dengan menggunakan Transformasi Fourier, yaitu nilai matriks dari citra yang sebelumnya berada pada domain spasial diubah ke domain frekuensi.

Pada Tugas Akhir ini digunakan metode Power Cepstrum untuk menyelesaikan permasalahan Registrasi Citra. Cepstrum merupakan hasil perolehan logaritma spektrum suatu sinyal yang ditransformasikan dengan menggunakan Transformasi Fourier. Power Cepstrum digunakan untuk mendapatkan besar pergeseran diantara kedua citra. Pada permasalahan satu dimensi, Power Cepstrum dari fungsi waktu adalah power spectrum dari logaritma dari power spectrum fungsi tersebut. Pada permasalahan dua dimensi, fungsinya diubah menjadi fungsi intensitas citra.

Dari uji coba yang telah dilakukan, tampak bahwa perangkat lunak Registrasi Citra menggunakan metode Power Cepstrum mampu mendeteksi pergeseran pada level piksel dengan nilai pergeseran maksimum sebesar 30 piksel.

Kata kunci: registrasi citra, power cepstrum, transformasi fourier, domain frekuensi
\end{abstract}




\section{Pendahuluan}

Kualitas citra merupakan hal yang paling krusial dalam semua bidang yang berbasis gambar. Citra yang berkualitas tinggi akan memudahkan pembacanya dalam memahami informasi yang terkandung didalamnya, sehingga mengurangi kesalahan yang mungkin terjadi. Berbicara mengenai kualitas citra, akan merujuk pada proses pengolahan citra, dimana pengolahan citra merupakan suatu proses yang dilakukan dengan masukan berupa citra dan hasilnya juga berupa citra[1] dengan tujuan untuk meningkatkan kualitas dari citra tersebut. Salah satu metode yang dapat digunakan dalam proses perbaikan citra adalah Super Resolusi, Super Resolusi merupakan suatu teknik yang digunakan untuk membangun citra beresolusi tinggi dari sekumpulan citra yang memiliki resolusi rendah[2].

Teknik Super Resolusi mempunyai dua langkah utama, yaitu registrasi citra dan rekonstruksi citra. Registrasi merupakan langkah terpenting dalam teknik Super Resolusi karena registrasi citra menentukan baik buruknya hasil dari perbaikan citra menggunakan Super Resolusi. Registrasi citra dapat diartikan sebagai proses untuk mendapatkan nilai pergeseran diantara citra beresolusi rendah yang melibatkan dua citra atau lebih yang memiliki objek sama namun diperoleh pada waktu, sudut pandang, dan sensor yang berbeda.

Dalam Tugas Akhir ini, akan diterapkan salah satu metode dari registrasi citra yaitu metode Power Cepstrum yang bekerja dalam domain frekuensi. Power Cepstrum dapat digunakan untuk mendeteksi parameter rotasi dan translasi yang lebih efisien dan cukup akurat. Metode ini diperkenalkan pertama kali oleh Bogert et al, dimana awalnya metode ini digunakan untuk menganalisis data yang mengandung echoes.

Power Cepstrum diperoleh dari logaritma spectrum sinyal yang kemudian ditransformasi menggunakan Transformasi Fourier. Metode ini mendapatkan nilai pergeseran dengan cara memproses nilai intensitas kedua citra referensi dan citra uji.

Tujuan dari penelitian ini adalah membangun sebuah program yang dapat mendeteksi besar pergeseran diantara dua citra menggunakan metode Power Cepstrum dengan asumsi tidak ada beda rotasi diantara kedua citra. Program yang akan dibangun diharapkan dapat berkontribusi untuk menentukan pergeseran titik piksel citra dalam teknik Super Resolusi, sehingga bermanfaat dalam proses perbaikan citra.

\section{Tinjauan Pustaka}

\subsection{Citra}

Istilah citra merujuk pada sebuah fungsi intensitas cahaya dua dimensi. Citra terbagi atas dua macam yaitu citra diskrit (citra digital) yang diperoleh melalui proses digitalisasi citra dan citra kontinu yang diperoleh melalui sistem optik yang menerima sinyal analog. Citra merupakan fungsi kontinu dari intensitas cahaya pada bidang dua dimensi yang dinyatakan dalam bentuk fungsi[5] $f(x, y)$ dengan $(x, y)$ menyatakan koordinat spasial pada bidang 
dua dimensi, $x$ merupakan nilai baris citra dan $y$ adalah nilai kolom citra, sehingga $f(x, y)$ menyatakan intensitas cahaya pada titik $(x, y)$ yang besarnya adalah $0<f(x, y)<\infty$. Model koordinat citra diberikan melalui gambar 2.1.

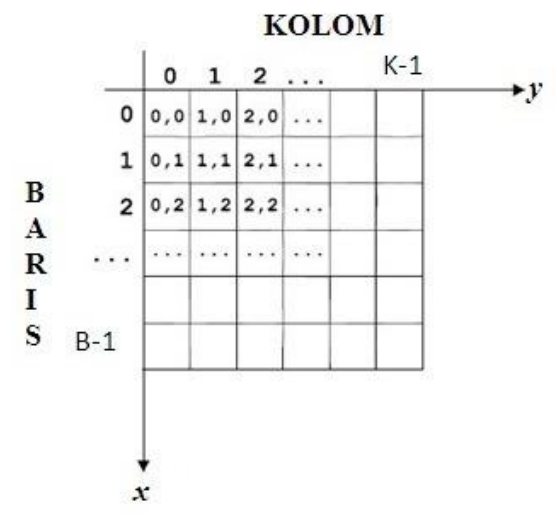

Gambar 2.1. Sistem Koordinat Citra

\subsection{Citra Digital}

Suatu citra $f(x, y)$, jika $x, y$, dan nilai amplitudo dari $f$ terbatas, maka citra tersebut disebut citra digital[3]. Citra digital diperoleh dari proses digitalisasi citra, yaitu proses pengubahan citra dari fungsi kontinu menjadi fungsi diskrit[1]. Secara umum, citra digital berbentuk persegi empat dengan dimensi ukurannya dinyatakan oleh panjang dan lebar. Misal suatu citra dengan panjang $M$ dan lebar $N$, dinyatakan dengan bentuk matriks yang berukuran $M$ x $N$ sebagai berikut[3]:

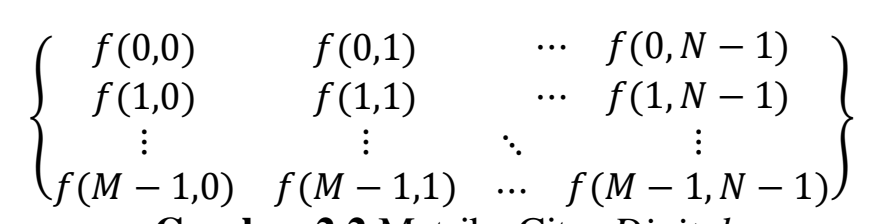

Gambar 2.2 Matriks Citra Digital

Sebuah citra digital dapat dipandang sebagai sebuah matriks yang mempunyai indeks baris dan kolom yang mewakili posisi sebuah titik dalam citra, dan elemen matriks yang terkait mengidentifikasi tingkat keabuan di titik tersebut.

\subsection{Pengolahan Citra Digital}

Pengolahan citra merupakan pemrosesan citra menggunakan komputer untuk mendapatkan citra yang kualitasnya lebih baik dari sebelumnya[10]. Pada hampir semua aplikasi pengolahan citra digital, diperlukan proses membandingkan dua atau lebih citra dari objek yang sama yang diperoleh pada waktu dan kondisi yang berbeda, namun akan sulit untuk menyamakan objek di posisi yang sama karena akan terdapat perbedaan rotasional atau translasional diantara dua citra tersebut. Sebelum dibandingkan, citra tersebut 
harus melalui proses registrasi, sehingga perbedaan rotasional dan translasional dapat dideteksi dan diperbaiki.

\subsection{Registrasi Citra}

Terdapat bermacam-macam definisi registrasi citra, diantaranya adalah registrasi citra merupakan proses overlay dua atau lebih citra dengan obyek yang sama, yang diambil pada waktu yang berbeda, dari sudut pandang yang berbeda, dan atau oleh sensor yang berbeda pula[12]. Definisi lain adalah proses menemukan kembali titik-titik yang bersesuaian antara citra $I_{1}$ dengan citra $I_{2}$ dimana citra $I_{2}$ yang mengalami transformasi geometri seperti pergeseran (translasi), rotasi, perbesaran (scaling), pembalikan (fliping), dan penarikan (stretching) [9]. Dua pengertian diatas, meskipun berbeda namun memiliki makna yang sama sehingga dapat disimpulkan bahwa registrasi citra merupakan suatu proses untuk mendapatkan hasil pergeseran diantara citra beresolusi rendah yang melibatkan dua citra atau lebih yang memiliki objek sama namun diperoleh pada waktu, sudut pandang, dan sensor yang berbeda.

Registrasi citra dapat dilakukan pada domain spasial dan domain frekuensi. Pada domain spasial, registrasi dilakukan dengan cara mencari nilai rata-rata, median, atau ukuran statistika lainnya pada setiap nilai derajat keabuan (gray scale) atau RGB[9]. Registrasi citra pada domain spasial akan bekerja dengan baik jika diaplikasikan pada citra yang memiliki tingkat ketidakteraturan yang cukup kecil, artinya adalah citra tersebut memiliki selisih nilai yang relatif kecil. Sedangkan pada domain frekuensi dilakukan dengan menggunakan Transformasi Fourier, yaitu nilai matriks dari citra yang sebelumnya berada pada domain spasial diubah ke domain frekuensi. Metode yang mengacu pada Transformasi Fourier mampu memberikan nilai rotasi yang besar, perbesaran, dan pergeseran untuk mendapatkan hasil registrasi yang lebih akurat dibandingkan dengan metode pada domain spasial. Konsep registrasi citra pada domain spasial dan frekuensi adalah estimasi pergeseran dan estimasi rotasi. Estimasi pergeseran diberikan sebagai berikut, misal $I_{2}$ adalah citra $I_{1}$ yang mengalami pergeseran sebesar $(\Delta x, \Delta y)$ maka

$$
I_{1}(x, y)=I_{2}(x+\Delta x, y+\Delta y)
$$

Untuk estimasi rotasi diberikan sebagai berikut. Jika $I_{2}$ adalah citra $I_{1}$ yang mengalami rotasi sebesar $\Delta \theta$, maka untuk menemukan sudut rotasi $\Delta \theta$ dilakukan dengan mengubah sistem koordinat kartesian pada citra $I_{1}$ dan $I_{2}$ menjadi sistem koordinat polar sehingga

$$
I_{1}(r, \theta)=I_{2}(r, \theta+\Delta \theta)
$$

Registrasi citra mendapatkan besar pergeseran berdasarkan pada koordinat piksel titik referensi. Titik referensi adalah koordinat titik piksel yang dipilih dari citra referensi, sedangkan titik corresponding merupakan 
koordinat titik piksel dari citra uji yang diperoleh setelah proses registrasi citra.

\subsection{Transformasi Fourier}

Karena pada Tugas Akhir ini menggunakan metode Registrasi Citra yang berdasar pada metode domain frekuensi, maka diperlukan Transformasi Fourier. Transformasi Fourier merupakan transformasi paling penting didalam bidang pengolahan sinyal, khususnya pada bidang pengolahan citra[10]. Transformasi Fourier merupakan peralatan (tools) untuk mengubah fungsi dari domain waktu/spasial ke domain frekuensi.

Transformasi Fourier terbagi menjadi dua yaitu kontinu dan diskrit. Dalam hal ini yang dibahas hanya Transformasi Fourier dua dimensi untuk bilangan bulat.

\subsubsection{Transformasi Fourier Kontinu}

Misalkan $f(x, y)$ adalah fungsi real kontinu dan terintegral dengan variabel bebas $x$ dan $y$, Transformasi Fourier dari $f(x, y)$ dinyatakan dengan $\mathfrak{I}\{f(x, y)\}$ dan didefinisikan pada persamaan $(2.3)$

$$
\mathfrak{I}\{f(x, y)\}=F(u, v)=\int_{-\infty}^{\infty} \int_{-\infty}^{\infty} f(x, y) \exp [-j 2 \pi(u x+v y)] d x d y
$$

dengan

$$
\begin{aligned}
& j=\sqrt{-1} \\
& u \text { dan } v \text { adalah variabel frekuensi. }
\end{aligned}
$$

Jika fungsi $F(u, v)$ diketahui, maka fungsi $f(x, y)$ dapat diperoleh dengan menggunakan invers Transformasi Fourier, sebagai berikut

\subsubsection{Transformasi Fourier Diskrit}

Misalkan ada fungsi kontinu $f(x)$, akan dilakukan proses diskritisasi $f(x)$ kedalam sebuah barisan sebagai berikut

$\left\{f\left(x_{0}\right), f\left(x_{0}+\Delta x\right), f\left(x_{0}+2 \Delta x\right), \ldots \ldots, f\left(x_{0}+(N-1) \Delta x\right)\right\}$

dengan mengambil sampel sebanyak $N$ yang memiliki selisih tetap sebesar $\Delta x$ satuan, dapat didefinisikan

$f\left(x_{k}\right)=f\left(x_{0}+k \Delta x\right)$

dengan $x$ diasumsikan sebagai nilai diskrit $0,1,2, \ldots, N-1$. Barisan $\{f(0), f(1), f(2), \ldots \ldots, f(N-1)\}$ menyatakan sebuah ruang sampel seragam dari sebuah fungsi kontinu $f(x)$. Sehingga Transformasi Fourier diskrit dari fungsi yang disampling tersebut diberikan oleh

$F(u)=\frac{1}{N} \sum_{x=0}^{N-1} f(x) \exp \left[-\frac{j 2 \pi u x}{N}\right]$

dengan $u=0,1,2, \ldots, N-1$ 
Perluasan dari Transformasi Fourier diskrit satu dimensi ke Transformasi Fourier diskrit dua dimensi dari fungsi citra $f(x, y)$ dengan ukuran $M \times N$ diberikan melalui persamaan (2.6):

$F(u, v)=\frac{1}{M N} \sum_{x=0}^{M-1} \sum_{y=0}^{N-1} f(x, y) e^{-j 2 \pi\left(\frac{u x}{M}+\frac{v y}{N}\right)}$

dengan nilai $u=0,1,2, \ldots \ldots, M-1$ dan $v=0,1,2, \ldots \ldots, N-1$

\subsection{Algoritma Registrasi Citra dengan Metode Power Cepstrum}

Untuk mendeteksi perbedaan diantara kedua citra referensi dan citra uji, maka kedua citra tersebut harus dibandingkan. Langkah yang harus dilakukan sebelum membandingkan kedua citra adalah kedua citra tersebut diregistrasi terlebih dahulu. Dengan adanya perbedaan diantara kedua citra, maka kesalahan dalam proses registrasi dapat terjadi. Algoritma Registrasi Citra dengan metode Power Cepstrum diberikan sebagai berikut[12]:

1. Penyederhanaan Citra (Simplifying Image)

2. Koreksi Perbedaan Rotasional (Rotation Correction)

3. Koreksi Pergeseran (Translation Correction)

Algoritma diatas ditunjukkan pada gambar 2.2. Tiga langkah diatas akan dijelaskan pada bagian ini.

\subsubsection{Penyederhanaan Citra}

Dalam proses Penyederhanaan Citra ini, terdapat empat operasi yang akan dilakukan. Empat operasi tersebut akan dijelaskan pada bagian ini, disertai alasan mengapa operasi ini digunakan dalam proses Penyederhanaan Citra.

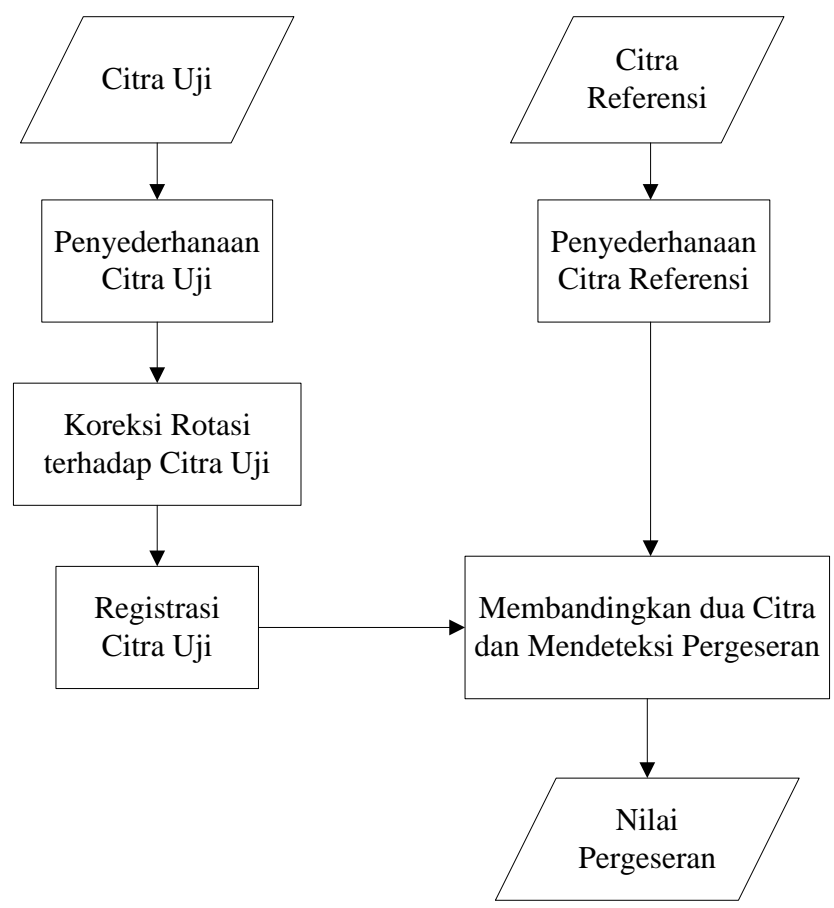

Gambar 2.3 Algoritma Registrasi Citra dengan Metode Power Cepstrum 
Operasi 1: Memilih subcitra

Karena adanya perbedaan rotasional dan translasional diantara kedua citra, maka kedua citra tersebut mengandung banyak informasi untuk registrasi citra. Namun tidak semua informasi dapat digunakan, sehingga perlu dilakukan proses pemilihan sub citra dari kedua citra masukan untuk memfokuskan area kerja dalam registrasi citra agar dapat meminimalkan kesalahan pendeteksian.

Operasi 2: Menyamakan intensitas kedua subcitra

Karena citra referensi dan citra uji diperoleh pada waktu dan kondisi yang berbeda, kemungkinan akan ada perbedaan iluminasi latar belakang diantara keduanya. Hal ini dapat menyebabkan munculnya kesalahan dalam proses koreksi perbedaan translasional. Cara termudah untuk menyesuaikan iluminasi adalah dengan menghitung intensitas rata-rata untuk kedua subcitra dan kemudian mengubah intensitas citra uji sesuai dengan perbedaan intensitas rata-rata diantara keduanya.

Operasi 3: Membinerkan kedua subcitra

Setelah memilih subcitra dan menyamakan intensitas rata-ratanya, dilakukan binarization enhancement (mengubah nilai subcitra menjadi biner) untuk menghapus informasi-informasi yang tidak penting. Hal ini dapat meminimalkan terjadinya kesalahan dalam registrasi. Karena intensitas ratarata dari citra uji telah diubah, maka hanya satu nilai threshold yang digunakan dalam operasi binarization. Operasi ini ditunjukkan pada persamaan (2.7).

$I_{b}(x, y)=\left\{\begin{array}{l}1, I_{\text {in }}(x, y) \geq T_{b} \\ 0, \text { yang lain }\end{array}\right.$

dengan

$I_{\text {in }}(x, y)$ : subcitra masukan

$I_{b}(x, y)$ : citra yang dibinerkan dengan nilai maksimum diberikan sebesar setengah dari skala gray level dari 0-255

$T_{b} \quad$ : nilai threshold

Operasi 4: Konvolusi dengan Operator Sobel

Tujuan dari operasi ini adalah meningkatkan sensitifitas dari algoritma registrasi ini, sehingga pendeteksian pergeseran akan lebih mudah dan lebih akurat. Operasi ini dilakukan dengan operator Sobel 3x3 yang diaplikasikan pada kedua sub citra untuk deteksi tepinya. Operator Sobel 3x3 yang digunakan dalam operasi ini diberikan sebagai berikut

$S_{1}=\left[\begin{array}{lll}-1 & 0 & 1 \\ -2 & 0 & 2 \\ -1 & 0 & 1\end{array}\right], \quad S_{2}=\left[\begin{array}{ccc}1 & 2 & 1 \\ 0 & 0 & 0 \\ -1 & -2 & -1\end{array}\right]$

Kemudian hasil $S(x, y)$ diperoleh sebagai berikut

$S(x, y)=\sqrt{\left[S_{1}\left(I_{b}\right)\right]^{2}+\left[S_{2}\left(I_{b}\right)\right]^{2}}$ 
Persamaan (2.8) di atas diselesaikan berdasarkan persamaan (2.9) di bawah ini

$I_{S}(x, y)=\left\{\begin{array}{cl}127, & S(x, y) \geq T_{S} \\ 0, & \text { yang lain }\end{array}\right.$

dengan

$I_{S}(x, y):$ citra biner

$S(x, y)$ : operator Sobel yang dioperasikan pada citra biner

$T_{S} \quad$ : nilai threshold untuk operator Sobel

Pada bagian ini, hanya informasi yang penting untuk registrasi dan yang umum untuk kedua gambar yang dipertahankan.

\subsubsection{Koreksi Rotasi}

Berdasarkan simulasi komputer, diketahui bahwa Power Cepstrum tidak mampu untuk mengoreksi kedua perbedaan rotasional dan translasional[6]. Hal ini dikarenakan, Power Cepstrum hanya didesain untuk mendeteksi perubahan translasional dan puncak cepstral akan menjadi kabur (blur) ketika citra yang dideteksi mengalami perubahan rotasional terhadap citra lainnya. Karena alasan tersebut, maka citra referensi dan citra uji perlu dirotasi terlebih dahulu sampai keduanya menjadi paralel, hanya perbedaan translasional yang tetap.

\subsubsection{Koreksi Pergeseran}

Setelah melalui proses Penyederhanaan dan Koreksi Rotasi, maka kedua sub citra saling berparalel, sehingga Power Cepstrum dapat diaplikasikan untuk mendeteksi parameter translasi. Karena kedua sub citra ini memiliki intensitas yang sama, maka magnitudes dari puncak cepstral yang pertama akan lebih mudah dideteksi.

Rumus Power Cepstrum didefinisikan sebagai berikut[13]

$$
P[I(x, y)]=\left|F\left\{\log |F\{I(x, y)\}|^{2}\right\}\right|^{2}
$$

\subsection{Power Cepstrum}

Metode Registrasi Citra yang digunakan pada tugas akhir ini adalah Power Cepstrum, dimana metode ini diperoleh melalui suatu proses yang memanfaatkan Transformasi Fourier. Cepstrum merupakan hasil perolehan logaritma spektrum suatu sinyal yang ditransformasikan dengan menggunakan Transformasi Fourier. Nama ini diperoleh dengan membalik 4 huruf pertama dari kata "spectrum". Teknik Cepstrum pertama kali diperkenalkan oleh Bogert pada tahun 1962[6]. Dasarnya, teknik Cepstrum digunakan untuk analisis data yang mengandung echoes. Teknik Cepstrum terdiri dari metode Power Cepstrum dan metode Complex Cepstrum. Power Cepstrum biasa digunakan untuk menentukan waktu kedatangan dari sinyal dan echoes-nya dan amplitudo relatifnya, sedangkan Complex Cepstrum 
digunakan untuk mendeteksi parameter echo dan menghapus echoes dari sinyal. Dalam hal ini, teknik Cepstrum yang digunakan adalah untuk sinyal dua dimensi dimana sinyal tersebut memiliki dua variabel, sehingga teknik ini dapat digunakan dalam proses pengolahan citra digital[12].

Dalam permasalahan satu dimensi, Power Cepstrum dari sebuah fungsi (fungsi yang dimaksud adalah fungsi waktu) adalah power spectrum dari logaritma power spectrum dari fungsi tersebut, sedangkan pada kasus dua dimensi, fungsinya diubah ke fungsi intensitas citra (fungsi dua dimensi). Untuk $I(x, y)$ Power Cepstrum dituliskan sebagai berikut:

Power Cepstrum $=\left|F\left\{\log |F\{I(x, y)\}|^{2}\right\}\right|^{2}$

dengan

$F \quad$ : notasi untuk fungsi Transformasi Fourier

$I(x, y)$ : superposisi dari citra referensi dan citra uji dimana terdapat perbedaan translasional diantaranya keduanya.

Asumsikan sebuah citra gabungan (composite image) $I(x, y)$ dituliskan sebagai berikut:

$I(x, y)=R(x, y)+S(x, y)=I(x, y)+a_{0} R\left(x-x_{0}, y-y_{0}\right)$

dengan

$R(x, y) \quad$ : citra referensi

$S(x, y) \quad$ : citra uji dari citra referensi yang digeser dengan amplitudo skala faktor $a_{0}$ dan perbedaan translasi sebesar $\left(x_{0}, y_{0}\right)$

Hasil dari aplikasi Power Cepstrum terhadap fungsi $I(x, y)$ adalah[13]

$$
\begin{aligned}
P[I(x, y)]=\mid & \left|F\left[\ln |R(u, v)|^{2}\right]\right|^{2}+A \delta(x, y)+B \delta\left(x \pm x_{0}, y \pm y_{0}\right) \\
& +C \delta\left(x \pm 2 x_{0}, y \pm 2 y_{0}\right)+D \delta\left(x \pm 3 x_{0}, y \pm 3 y_{0}\right)+\cdots \ldots \ldots
\end{aligned}
$$

dengan

$P[\bullet \quad$ : notasi untuk Power Cepstrum dari fungsi

$A, B, C, D:$ konstanta

Setelah mengurangkan $P[R(x, y)]$ dari $P[I(x, y)]$, perbedaan translasional diantara dua subcitra dapat dideteksi dengan memeriksa rangkaian sinyal yang tersisa. Dengan kata lain, perbedaan translasional setara dengan puncak pertama $\delta\left(x-x_{0}, y-y_{0}\right)$ yang terjadi pada bidang cepstral. Nilai dari konstanta $A, B, C, D, \ldots$ akan lebih besar jika amplitudo skala faktornya $a_{0}$ menuju 1 . Catat bahwa untuk meningkatkan puncak cepstral, cepstrum dari citra referensi dikurangkan dari cepstrum dari citra referensi ditambah citra uji. 


\section{Perancangan dan Implementasi Program}

\subsection{Perancangan sistem}

Perancangan sistem dilakukan untuk mengetahui gambaran keseluruhan dari proses kerja sistem program yang dibuat, bagaimana sistem program berinteraksi dengan user mulai dari memasukkan data sampai menghasilkan keluaran. Seluruh proses yang dilakukan dalam Registrasi Citra digambarkan sebagai berikut:

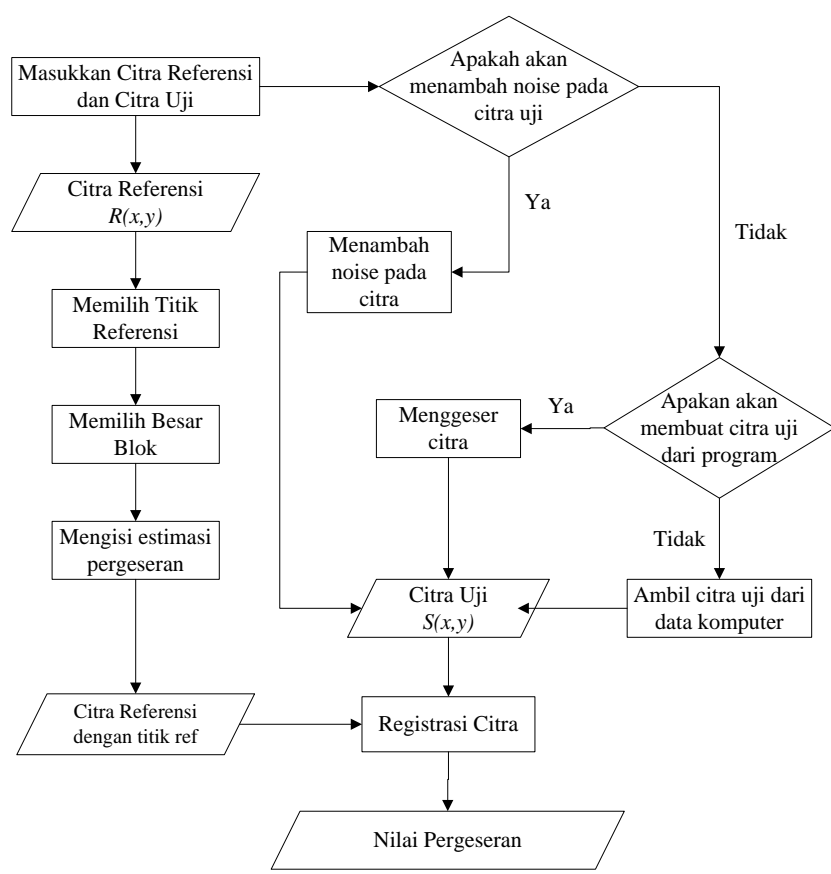

Gambar 2.4 Diagram alir proses keseluruhan pada sistem

\subsubsection{Proses Registrasi Citra}

Proses ini bertujuan untuk mendapatkan nilai pergeseran diantara kedua citra masukan. Langkah yang dilakukan dalam proses ini meliputi Penyederhanaan Citra, Koreksi Rotasi, dan Koreksi Pergeseran. Karena dalam penelitian ini diasumsikan bahwa beda rotasional diantara kedua citra tidak ada, maka yang dilakukan hanya Simplify dan Koreksi Translasi menggunakan Power Cepstrum. Kedua langkah tersebut ditunjukkan melalui gambar 2.5 dan dijelaskan dibawah ini:

1. Penyederhanaan Citra

Langkah ini bertujuan untuk menyederhanakan citra masukan sehingga citra yang diolah hanya yang mengandung informasi terpenting saja. Rangkaian kegiatan yang dilakukan pada langkah ini adalah:

a. Memilih area kerja

Fungsi kegiatan ini adalah memilih sub citra pada kedua citra dengan tujuan untuk memfokuskan area kerja dalam Registrasi Citra. Sub citra yang dipilih harus memuat informasi yang dibutuhkan dalam proses Registrasi Citra. 
b. Menyamakan nilai intensitas

Kegiatan ini bertujuan untuk menyamakan nilai intensitas kedua citra dengan cara menghitung intensitas rata-rata untuk kedua sub citra kemudian mengubah intensitas citra uji sesuai dengan hasil perhitungan. Tujuannya adalah memudahkan pada proses binarisasi citra.

c. Membinerkan nilai citra

kegiatan selanjutnya adalah membinerkan nilai dari kedua citra referensi dan citra uji.

d. Implementasi Operator Sobel

Kegiatan ini dilakukan untuk meningkatkan sensitifitas dari algoritma Registrasi ini.

2. Koreksi Pergeseran

Setelah melalui proses Penyederhanaan, maka kedua sub citra saling berparalel sehingga Power Cepstrum dapat diaplikasikan untuk mendeteksi nilai pergeserannya.

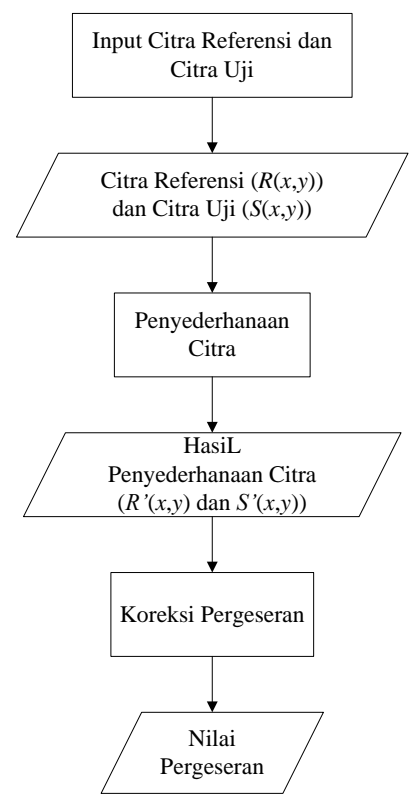

Gambar 2.5 Diagram Alir Proses Registrasi Citra

\subsubsection{Power Cepstrum}

Power Cepstrum diperoleh melalui proses Transformasi Fourier dan logaritma natural yang dikenakan pada fungsi citra $I(x, y)$. Rumus umum dari metode Power Cepstrum dituliskan pada persamaan (2.14) berikut ini:

Power Cepstrum $=\left|F\left\{\ln \left[|F\{I(x, y)\}|^{2}\right]\right\}\right|^{2}$

dengan $F$ adalah notasi untuk fungsi Transformasi Fourier dan fungsi $I(x, y)$ merupakan gabungan citra referensi dan citra uji dimana diantara dua citra ini terdapat perbedaan translasional. Diasumsikan sebuah citra gabungan $I(x, y)$ dapat dituliskan sebagai berikut: 
$I(x, y)=R(x, y)+S(x, y)=R(x, y)+a_{0} R\left(x-x_{0}, y-y_{0}\right)$

dengan $R(x, y)$ adalah citra referensi

$S(x, y)$ adalah citra uji dengan amplitudo skala faktor dan perbedaan translasi berturut-turut sebesar $a_{0}$ dan $\left(x_{0}, y_{0}\right)$

Sehingga hasil dari pengaplikasian Power Cepstrum pada fungsi $I(x, y)$ adalah

$$
\begin{aligned}
P[I(x, y)]=\mid F\{ & \left.\ln \left[a_{0}{ }^{2}|R(u, v)|^{2}\right]\right\}\left.\right|^{2}+A_{0} \delta(x, y)+B_{0} \delta\left(x-x_{0}, y-y_{0}\right) \\
& +C_{0} \delta\left(x-2 x_{0}, y-2 y_{0}\right)+D_{0} \delta\left(x-3 x_{0}, y-3 y_{0}\right)+\cdots \cdots \cdots
\end{aligned}
$$

dengan

$$
\begin{aligned}
A_{0} & =\frac{1}{a_{0}{ }^{2}}-\frac{1}{2 a_{0}{ }^{4}}+\frac{1}{3 a_{0}{ }^{6}}-\cdots \cdots+\cdots \cdots \\
B_{0} & =\frac{2}{a_{0}}-\frac{2}{a_{0}{ }^{3}}+\frac{2}{a_{0}{ }^{5}}-\cdots \cdots+\cdots \cdots \\
C_{0} & =-\frac{2}{a_{0}{ }^{2}}+\frac{4}{a_{0}{ }^{4}}-\cdots \cdots+\cdots \cdots \\
D_{0} & =\frac{8}{3 a_{0}{ }^{3}}-\cdots
\end{aligned}
$$

\section{Uji Coba dan Pembahasan}

Untuk uji coba pertama menggunakan citra yang diketahui nilai pergeserannya. Langkah pertama adalah membuat citra uji dari citra referensi. Citra yang digunakan adalah Street.bmp yang kemudian digeser sebesar $(3,1)$ sehingga dihasilkan citra uji Street3-1.bmp sebagai citra uji.

Untuk uji coba yang kedua menggunakan citra bernoise, yaitu citra Street.bmp yang telah diberi noise salt\&pepper yaitu citra StreetSalt.bmp. Kemudian citra bernoise ini digeser sebesar $(3,1)$ menjadi StreetSalt3-1.bmp yang berperan sebagai citra uji.

\subsection{Pelaksanaan Uji Coba}

Uji coba dilakukan pada citra Street.bmp, dengan keterangan sebagai berikut:

Citra Referensi : Street.bmp

Citra Uji : Street3-1.bmp

Ukuran Citra : $768 \times 576$

Jenis Citra : grayscale

Besar Pergeseran : $x_{0}=3$ dan $y_{0}=1$

Hasilnya ditunjukkan melalui tabel 4.1

Uji coba kedua dilakukan dengan citra bernoise dengan keterangan sebagai berikut:

Citra Referensi : StreetSalt.bmp

Citra Uji : StreetSalt3-1.bmp 
Ukuran Citra : $768 \times 576$

Jenis Citra : grayscale

Besar Pergeseran : $x_{0}=3$ dan $y_{0}=1$

Hasilnya ditunjukkan melalui tabel 4.2

\subsection{Evaluasi}

Berdasarkan uji coba yang telah dilakukan, Power Cepstrum dapat mendeteksi besar pergeseran diantara kedua citra referensi dan citra uji dengan besar pergeseran antara 0 sampai 30 piksel, data uji coba lengkap dapat dilihat pada lembar lampiran. Hasil uji coba terbaik diperoleh ketika nilai estimasi pergeseran yang dipilih berada di sekitar nilai pergeseran yang sebenarnya dengan perbedaan nilai tidak lebih dari 2 piksel.

Untuk pengujian yang melibatkan citra bernoise terhadap citra referensi Street.bmp dan citra uji streetSalt3-1.bmp, Power Cepstrum dapat mendeteksi besar pergeseran dengan cukup akurat pada 4 nilai estimasi pergeseran yaitu pada nilai estimasi $(1,0),(1,1),(2,0)$, dan $(3,0)$. Sedangkan hasil uji coba terhadap citra yang tidak diketahui pergeserannya, hasil pendeteksian belum bisa digunakan untuk menunjukkan nilai pergeseran yang sebenarnya.

Tabel 4.1 Hasil Uji Coba Street.bmp

\begin{tabular}{|c|c|c|c|c|c|}
\hline \multicolumn{2}{|c|}{$\begin{array}{l}\text { Titik } \\
\text { Awal }\end{array}$} & \multirow[t]{2}{*}{ Titik Ref } & \multicolumn{2}{|c|}{$\begin{array}{c}\text { Besar } \\
\text { Pergeseran }\end{array}$} & \multirow[t]{2}{*}{ Titik Corr } \\
\hline $\mathrm{x} 0$ & $\mathrm{y} 0$ & & $\mathrm{x}$ & $\mathrm{y}$ & \\
\hline 6 & 3 & $(309,535)$ & 7 & 4 & $(316,539)$ \\
\hline 6 & 4 & $(194,604)$ & 19 & 6 & $(213,610)$ \\
\hline 6 & 5 & $(204,165)$ & 7 & 6 & $(211,171)$ \\
\hline 6 & 6 & $(95,418)$ & 7 & 7 & $(102,425)$ \\
\hline 6 & 7 & $(334,535)$ & 10 & 8 & $(344,543)$ \\
\hline 6 & 8 & $(67,474)$ & 7 & 9 & $(74,483)$ \\
\hline 6 & 9 & $(431,693)$ & 14 & 10 & $(445,703)$ \\
\hline 6 & 10 & $(215,703)$ & 8 & 30 & $(223,733)$ \\
\hline 7 & 3 & $(477,91)$ & 16 & 4 & $(493,95)$ \\
\hline 7 & 4 & $(401,555)$ & 9 & 5 & $(410,560)$ \\
\hline 7 & 5 & $(225,507)$ & 10 & 6 & $(235,513)$ \\
\hline 7 & 6 & $(217,78)$ & 9 & 7 & $(226,85)$ \\
\hline
\end{tabular}

Tabel 4.2 Hasil Uji Coba StreetSalt.bmp

\begin{tabular}{|c|c|c|c|c|c|}
\hline \multicolumn{2}{|c|}{$\begin{array}{l}\text { Titik } \\
\text { Awal }\end{array}$} & \multirow{2}{*}{ Titik Ref } & \multicolumn{2}{|c|}{$\begin{array}{c}\text { Besar } \\
\text { Pergeseran }\end{array}$} & \multirow{2}{*}{$\begin{array}{l}\text { Titik } \\
\text { Corr }\end{array}$} \\
\hline $\mathrm{x} 0$ & y0 & & $\mathrm{X}$ & $\mathrm{y}$ & \\
\hline 1 & 0 & $(107,104)$ & 2 & 1 & $(109,105)$ \\
\hline 1 & 1 & $(128,680)$ & 2 & 2 & $(130,682)$ \\
\hline 1 & 2 & $(523,117)$ & 6 & 3 & $(529,120)$ \\
\hline
\end{tabular}




\begin{tabular}{|c|c|c|c|c|c|}
\hline 1 & 3 & $(503,655)$ & 22 & 4 & $(525,659)$ \\
\hline 1 & 4 & $(255,196)$ & 3 & 5 & $(258,201)$ \\
\hline 1 & 5 & $(179,484)$ & 5 & 6 & $(184,490)$ \\
\hline 2 & 0 & $(482,165)$ & 3 & 1 & $(485,166)$ \\
\hline 2 & 1 & $(209,568)$ & 3 & 30 & $(212,598)$ \\
\hline 2 & 2 & $(227,224)$ & 3 & 3 & $(230,227)$ \\
\hline 2 & 3 & $(278,601)$ & 4 & 4 & $(282,605)$ \\
\hline 2 & 4 & $(462,655)$ & 3 & 5 & $(465,660)$ \\
\hline 2 & 5 & $(115,372)$ & 3 & 30 & $(118,402)$ \\
\hline
\end{tabular}

\section{Kesimpulan dan Saran}

\subsection{Kesimpulan}

Berdasarkan hasil pengujian perangkat lunak yang dilakukan pada Bab $\mathrm{V}$, maka diperoleh kesimpulan sebagai berikut:

a. Power Cepstrum tidak dapat mendeteksi pergeseran pada citra yang intensitasnya relatif homogen, yaitu citra yang memiliki warna background yang sama. Hal ini dapat dilihat pada hasil uji coba terhadap citra referensi pic1.bmp dengan pic7-5.bmp dan citra referensi kuning0.tif dengan kuning9-13.tif .

b. Power Cepstrum mampu mendeteksi pergeseran pada citra yang diberi tambahan noise. Data hasil uji cobanya dapat dilihat pada lampiran, yaitu uji coba dengan citra uji blurGaussian, blurPoisson, irisSpeckle, dan StreetSalt.

c. Berdasarkan hasil uji coba yang diberikan pada lampiran, Power Cepstrum mampu mendeteksi pergeseran untuk level piksel yang besar pergeseran maksimumnya sebesar 30 piksel.

\subsection{Saran}

Saran yang dapat diberikan untuk pengembangan Tugas Akhir ini antara lain:

a. Menambahkan fungsi interpolasi untuk mendeteksi pergeseran pada level sub piksel.

b. Untuk pengembangan perangkat lunak, uji coba pada citra yang tidak diketahui pergeserannya, dapat diberikan masukan citra yang diperoleh langsung dari frame pada suatu video.

\section{Daftar Pustaka}

[1] Basuki, A. Palandi, JF. Fatchurrochman. 2005. "Pengolahan Citra Digital Menggunakan Visual Basic". Yogyakarta: Graha Ilmu.

[2] Fadlisyah. 2007. "Computer Vision dan Pengolahan Citra". Yogyakarta: CV. ANDI OFFSET.

[3] Gonzales, RC. Woods, RE. 2002. "Digital Image Processing". New Jersey: Prentice Hall, Inc. 
[4] Jain, A.K. 1995. "Fundamentals of Digital Image Processing". Englewood Cliffs, J., U.S.A: Prentice Hall, Inc.

[5] Lee, D.J. 1987. "Image Registration Using Power Spectrum and Cepstrum Technique". Thesis. Electrical Engineering, Texas Tech University.

[6] Lee, D.J. Krile, T.F. Mitra, S. 1988. "Power Cepstrum and Spectrum Technique Applied to Image Registration". Jurnal. Applied Optics, Optical Society of America.

[7] Lee, D.J. Zhan, P. Thomas, A. Schoenberger, R. 2004. "Shape-based Human Detection for Threat Assesment". Orlando, Florida, USA. SPIE International Symposium on Defense and Security. Visual Information Processing XIII. Vol 5438. Hal 81-91.

[8] Lehman, TM. Goerke, C. Kaupp, A. Schmitt, W. Repges, R. 1996. “A Rotation - extended CepstrumTechnique and Its Application to Medical Images. Jurnal. Pattern

[9] Muchlisuddin. 2009. "Teknik High Accuracy Image Registration Menggunakan Fungsi Phase Only Correlation" Tugas Akhir, Institut Teknologi Sepuluh Nopember.

[10] Munir, Rinaldi. 2004. "Pengolahan Citra Digital dengan Pendekatan Algoritmik". Diktat Kuliah Departemen Teknik Informatika ITB. Bandung.

[11] Wijaya, AY. Arifin, AZ. Purwitasari, D. 2010. "Algoritma Pemutusan Rantai Iteratif pada Registrasi Citra dengan Menggunakan Pseudopolar Fourier Transform". Paper, Jurusan Teknik Informatika ITS Surabaya.

[12] Zitova, B. Flusser, J. 2003. "Image Registration Methods: a survey". Jurnal. Czech Republic ELSEVIER. Hal 977-1000. 